\title{
AN ETHNOBOTANICAL STUDY OF WILD MEDICINAL PLANTS USED BY MIGRATORY SHEPHERDS - A TRIBAL COMMUNITY OF WESTERN HIMALAYAS
}

\author{
RADHA $^{1 *}$, PURI $\mathbf{S}^{1}$, KUMAR S \\ ${ }^{1}$ Department of Botany, School of Biological and Environmental Sciences, Shoolini University of Biotechnology and Management Sciences, \\ Solan, Himachal Pradesh, India. ${ }^{2}$ Department of Botany, College of Horticulture and Forestry, Neri, Hamirpur, Himachal Pradesh, India. \\ Email: radhuchauhan7002@gmail.com \\ Received: 31 December 2018, Revised and Accepted: 21 February 2019
}

ABSTRACT

Objectives: Migratory shepherds of Kinnaur, Shimla, and Sirmaur districts in Himachal Pradesh of the western Himalayas have rich traditional knowledge of medicinal plants and its uses, in this respect; an ethnobotanical survey was carried out from 2017 to 2018.

Methods: The required information on ethnomedicines used by tribal migratory shepherds was collected through personal field visits, interview method and using a pretested questionnaire.

Results: It was observed that in all 78 species were used by shepherds en route from high hills to low hills. In high hills 35 species, in mid hills 20 species, and low hills 23 species were found to be used as ethnomedicine source.

Conclusion: This study shows that shepherds in tribal areas are highly dependent on ethnobotanical remedies, which evolved over generations of experience and practices, for health care. The common diseases were treated by ethnomedicinal plants such as cough, cold, body pain, Skin infection, wounds, diarrhea, respiratory problems, and sunburn. The collected detailed information on the list of plants and their therapeutic practices among tribal migratory shepherds may be helpful to improve the future pharmaceutical applications.

Keywords: Ethnomedicines, Shepherds, Livestock, Biodiversity.

(c) 2019 The Authors. Published by Innovare Academic Sciences Pvt Ltd. This is an open access article under the CC BY license (http://creativecommons. org/licenses/by/4. 0/) DOI: http://dx.doi.org/10.22159/ajpcr.2019.v12i4.31130

\section{INTRODUCTION}

The Indian Himalayan region is characterized by its unique ecosystem with a wide range of climates and habitat types which supports different flora and fauna [1]. The Himalaya Hotspot is home to the world's highest mountains. The mountains of Himalaya rise abruptly, resulting in a variety of ecosystems [2]. Himachal Pradesh, a North Indian state, is located in the western part of the Himalaya. The state has a wide geographical area $\left(55,673 \mathrm{~km}^{2}\right)$ and altitudinal variation (350-7000 m amsl) with a rich assortment of biotic components [3]. Himachal Pradesh has a forest cover of $26 \%$ and rich in medicinal plant species. The plant medications of inhabitants, handed down by word of mouth from one generation to the next generation, gradually became part of the knowledge of ancient civilization [4-8]. Majority of the rural societies possess significant traditional knowledge of natural resources, which they have inherited from their forefather. They closely depend on this knowledge for a variety of reasons related to the social order, health care, economy, shelter, food, etc. However, if the efforts are not made with instant effect, the rich traditional knowledge possessed by tribal society will diminish soon. This calls for an urgent need to document ethnomedicinal plant species. Ethnobotanical information is already given by many workers in different districts of Himachal Pradesh such as Lahaul and Spiti, Chamba, Mandi, and Kinnaur [9-13]. Moreover, Himachal Pradesh has led to tribal ways of life, adherence to the primitive customs and myths and traditions representing on enormous and difficult terrain of scattered human settlement [14]. The present study is an effort to enhance such surveys and make an addition to utilization of some of the wild medicinal plant species by tribal migratory shepherds which are not recorded earlier from the studied sites. The ethnobotanical information on medicinal plant species of the studied area is expected to provide new dimension's forever expanding the pharmaceutical industry.

\section{METHODS}

Himachal Pradesh, a North Indian state, is situated in the heart of Western Himalaya and has a varied geographical grouping, mosaic sociocultural diversity and huge wealth of natural resources $[15,16]$. The present study is undertaken in Himachal Pradesh situated between $75^{\circ} 45^{\prime} 55^{\prime \prime}-79^{\circ} 04^{\prime} 20^{\prime \prime} \mathrm{E}$ longitude and $30^{\circ} 22^{\prime} 40^{\prime \prime}-33^{\circ} 12^{\prime} 40^{\prime \prime} \mathrm{N}$ latitude. Physiographically, the state consists of three distinct regions outer Himalaya, mid-Himalaya, and greater Himalaya. The outer Himalaya, also called Shivalik hills, ranges from 350 to $1500 \mathrm{amsl}$. The mid hills cover an area up to $3500 \mathrm{~m}$. The greater Himalaya also called a high altitude alpine zone generally starts from an elevation of $3510 \mathrm{~m}$ and above. It includes higher altitude areas of Kullu, Kinnaur, LahulSpiti, and Chamba districts. Due to diverse ecological conditions and altitudinal differences, the state is rich in plant species, which includes around 3400 species of flowering plants ranging from alpine to tropical zone [1].

Kinnaur district of Himachal Pradesh is well known for migratory shepherding, where the shepherds move from their places to low hills on a set route to enter sites in Shimla and Sirmaur districts. The present study documents the use of ethnomedicines used by migratory shepherds of district Kinnaur Himachal Pradesh. A total of five field surveys were carried out taking into account the migratory route of the shepherds from high hills to low hills. In the higher reaches of Kinnaur district, the Kinnaure (shepherds) started the movement from five different villages of Kinnaur and these were Kamru, Sangla, Batseri, Rakchham, and Chitkul. Besides, the place of origin of shepherds, surveys were done for four other places, namely - Chopal, (mid hills), Churdhar (mid hills), Renukaji (low hills), and Poanta-Sahib (low hills). These four places were their part of the migratory route. The migratory shepherd's groups were selected randomly for an interview during field visits. 


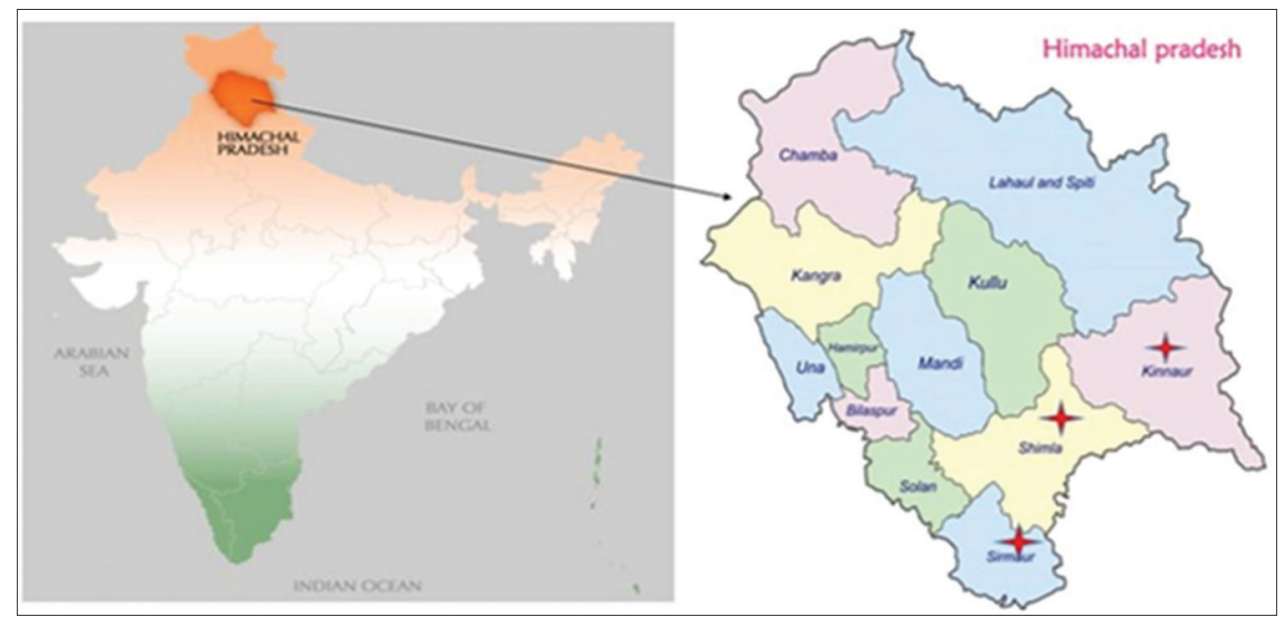

Fig. 1: Map of India showing the districts of Kinnaur, Shimla, and Sirmaur of Himachal Pradesh

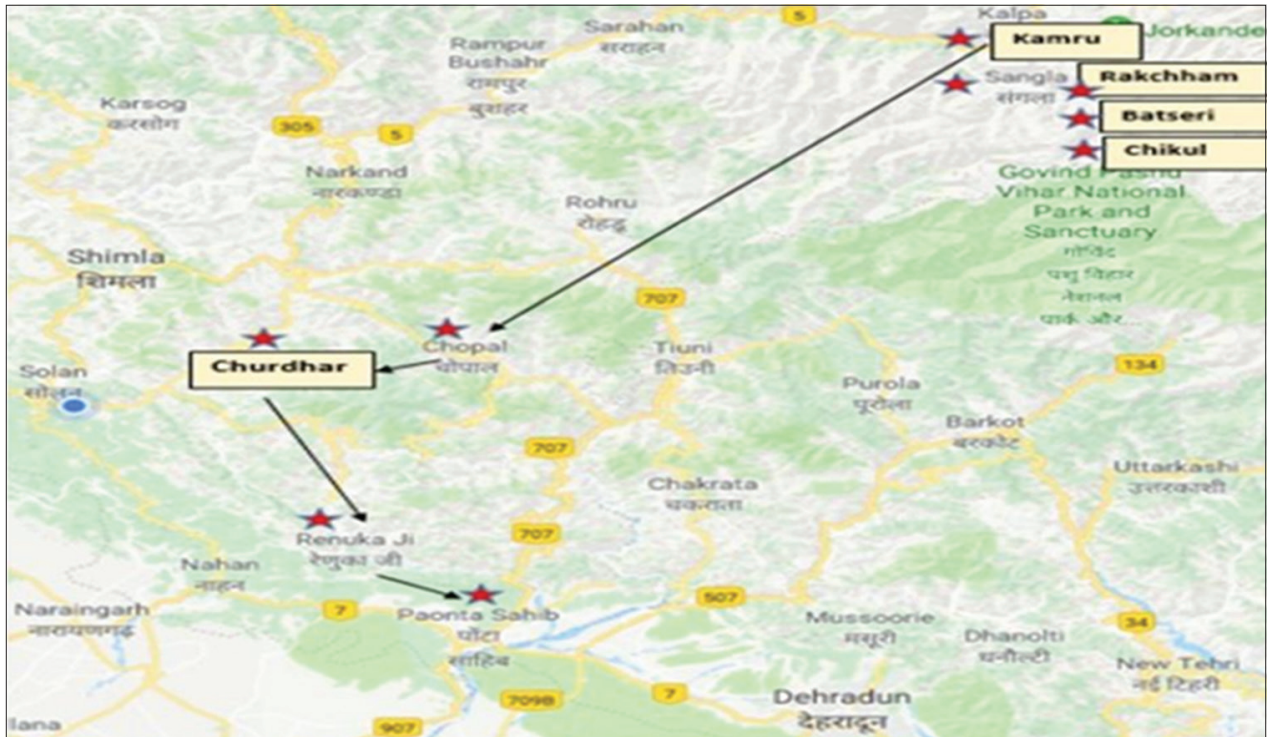

Fig. 2: Satellite map showing routes of shepherds from their originated villages Chitkul, Rakchham, Batseri, Sangla and Kamru (High hills) to Chopal and Churdhar (Mid hills) to the final destination Renukaji and Poanta-Sahib Sirmaur (Low hills)

Table 1: Basic information of tribal migratory shepherds in study sites of district Kinnaur, Himachal Pradesh

\begin{tabular}{|c|c|c|c|c|c|c|}
\hline \multirow[t]{2}{*}{ S. No. } & \multirow[t]{2}{*}{ Particulars } & \multicolumn{5}{|c|}{ Study villages } \\
\hline & & Kamru & Sangla & Batseri & Rakchham & Chitkul \\
\hline 1. & Altitude & $2700 \mathrm{~m}$ & $2600 \mathrm{~m}$ & $2700 \mathrm{~m}$ & $3100 \mathrm{~m}$ & $3450 \mathrm{~m}$ \\
\hline 3. & Average family income (Rs., Lakh/annum) & 3 & 2 & 4 & 2 & 3 \\
\hline 4. & Horses (No.) & 2 & 2 & 4 & 2 & 3 \\
\hline 5. & Dogs (No.) & 2 & 3 & 4 & 2 & 3 \\
\hline 6. & Flock size (sheep and goats) & 654 & 712 & 990 & 640 & 780 \\
\hline
\end{tabular}

Shepherds migration started from Kamru (2700 m), Sangla (2600 m), Batseri (2700 m), Rakchham (3100 m), and Chitkul(3450 m) in July. These originated sites of migratory shepherds located at high altitude remain cutoff from the rest of the world due to heavy snowfall during winters. The information on ethnobotanical medicines was collected using a pre-tested questionnaire, interview, through participatory discussion and observation from July 2017 to October 2018. The specimens of ethnobotanical medicines being used by migratory shepherds for their health care were collected, dried, and mounted on herbarium sheets, with label information describing when and where they were collected. Plants were identified either in the field itself or with the help of experts from Botanical Survey of India (BSI) Dehradun Uttarakhand and Forest
Research Institute (FRI) Dehradun, Uttarakhand. Vouchers of plants were places in the herbarium of Shoolini University, Solan [17].

\section{RESULTS}

Harsh environmental conditions cause seasonal migration of shepherds from high hills to low hills in Himachal Pradesh (Fig. 1). Seasonal migration is a traditional process in the tribes of the Himalayan region. It was observed that the majority of shepherds start their migration from their villages (Fig. 2) in July. However, a few also migrate in August and September, but there is no migration as the winters sets in. The migratory shepherds move in a group of their family members. The 


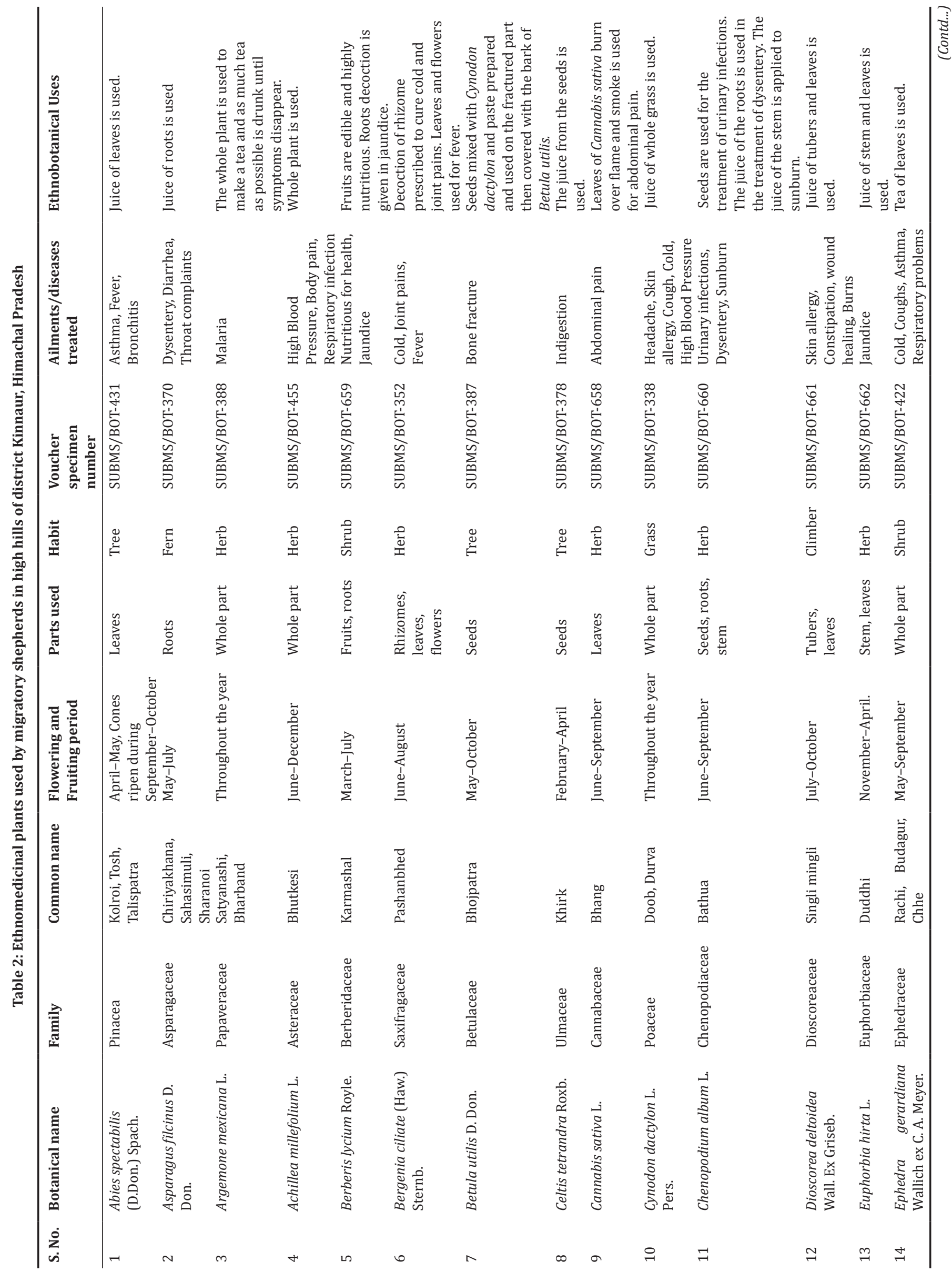




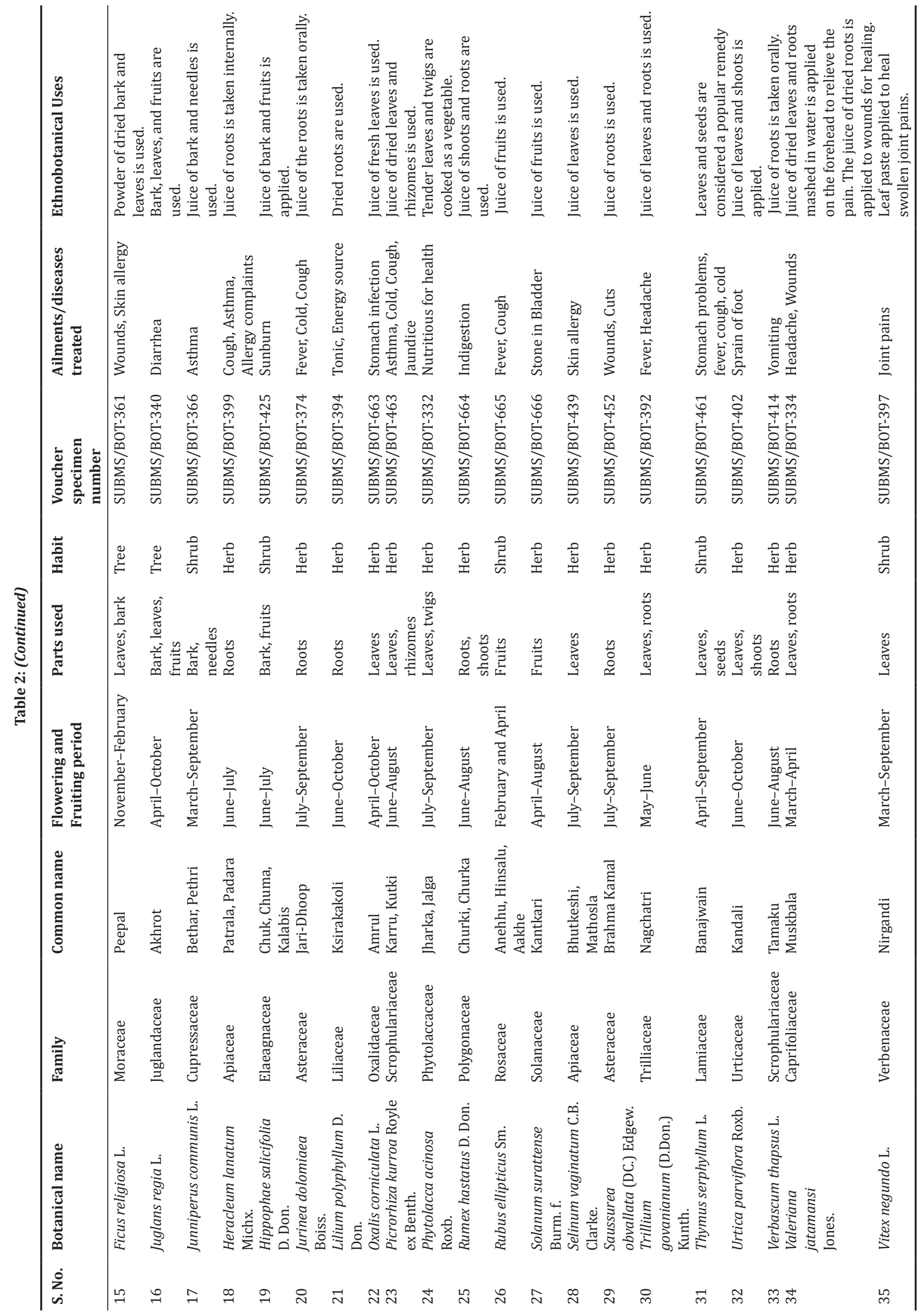




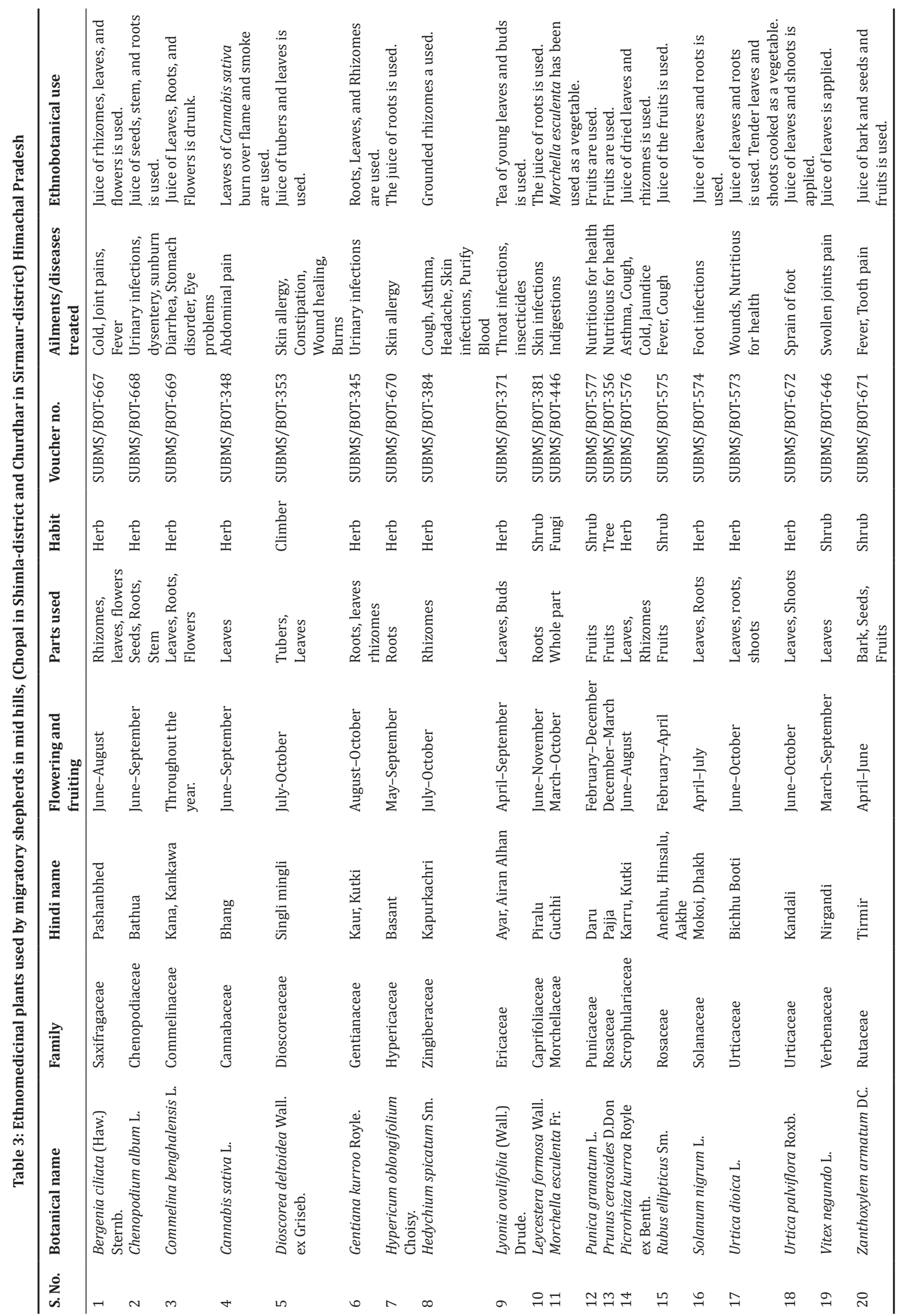




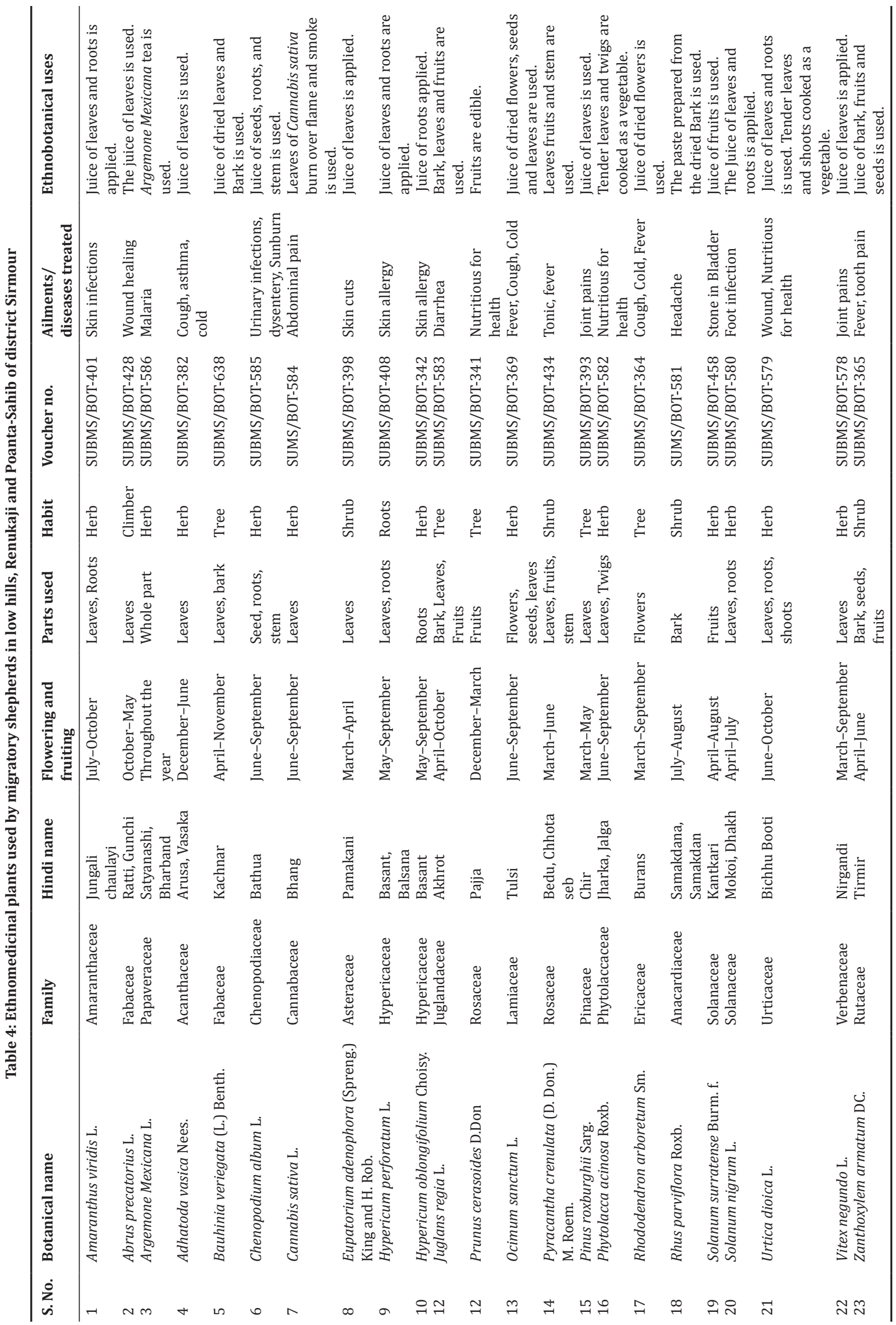




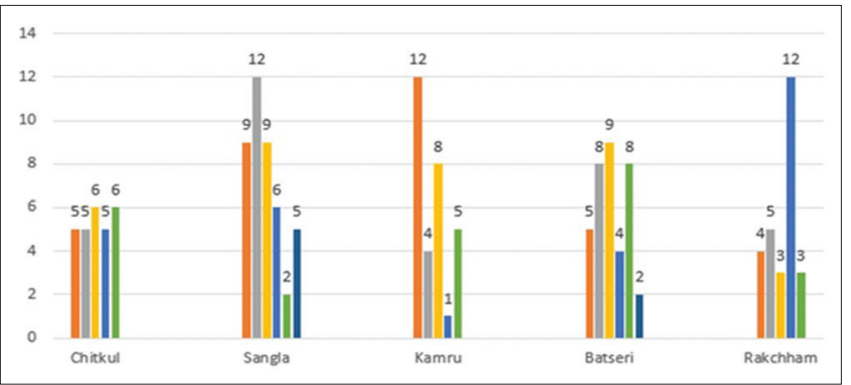

Fig. 3: Educational qualification of shepherds in five villages

migration flock includes both goats and sheep and size of the flock varies (Table 1). Shepherds move first to grazing pasture in Chopal (district Shimla) irrespective of their origin place of migration. The shepherds take along with them 2-4 horses for carrying tents and provisions. Often four to five dogs also accompany the shepherds, and in fact, these dogs are trained in protecting the goats and sheep from wild animals and also keep the flock together. The disparity of flock size generally is an indicator of the status of farmer's livestock holding capacity. The present study also indicated that shepherds having a high number of the flock are comparatively well off compared to those with less number. Many studies have reported that flock size is directly associated with migration distance, flock with larger size travel longer distance as compared to small size flocked $[18,19]$. In our study, it was found that irrespective of flock size, the shepherds travel the same distance. In the second stage, the shepherds then move to Churdhar ranges and from here to Renukaji in Sirmaur district. The routes of migration are generally fixed (Fig. 2) and proper permission is obtained from the authorities for the purpose. Finally, in the months of September-October, they reach the low hills in Poanta-Sahib in Sirmaur district and temporarily settle here up to March, and start their return journey to their respective places by end March (spring season). It was also observed that the shepherds are not highly qualified and it varied from $1^{\text {st }}$ class to $12^{\text {th }}$ class (Fig. 3 ).

The present studies revealed that the livelihood of shepherd's family is dependent either getting food and fruits from the forests/trees on the path they transect and selling the meat and milk products from their herds. The wild plants not only serve as their food but also for their livestock. It was observed that during their migration from upper hills to lower hills a total of 78 medicinal species were being used by the migratory shepherds, and a few of these belonged to the same families. All these medicinal plants are an integral part of shepherd's health-care during migration (Tables 2-4). The collection of various medicinal plants and plant parts varied from plant to plant, depending on their availability and usability. During their seasonal migration, the shepherds are much dependent on forest products for their requirements of fruits, vegetables, and medicines.

As the shepherds move from their respective place of origin (high hills), it was noted that 35 species (herbs, shrubs, and trees) were found to be used by the shepherds for their health care (Table 2). Interestingly, the shepherds informed that their preference for medicine is Picrorhiza kurroa (herb) as it is one of the important in medicines in their tribe. Similarly, in the mid-hills 20 plant species were found to be taken as medicine as the shepherds move toward Shimla hills (Table 3). Some of the medicinal plant species such as Chenopodium album, Berginia ciliata, Cannabis sativa, Dioscorea deltoidea, Picrorhiza kurroa, and Urtica palviflora found in mid hills were also present in higher hill regions (Table 3). Three species, namely Cannabis sativa, Vitex negundo, and Zanthoxylem armatum were frequently used for medicinal purposes. The use of many of these medicinal plants has also been reported by many workers from different parts of Himachal Pradesh $[20,21]$.

Due to variation in climatic conditions from high hills to low hills (Table 4), shepherds were commonly affected by many common diseases such as cough, asthma, cold, skin allergy, and fever. Five species from low hills, namely Adhatoda vasica, Hypericum oblongifolium, Rhododendron arboretum, and Urtica dioica were frequently used by shepherds to treat common diseases. The shepherds during migration generally move along the roadside and rarely adopt bridal pathways or shortcuts. For their own stay, they use makeshift tents and shift tents frequently within 5-6 days. There is always a scarcity of food and fodder for themselves and livestock. For this, they explore adjoining areas, particularly degraded lands, fallow fields, and village commons. It was interesting to note that their migration patterns closely mirrors the seasonal availability of natural food, fodder, and medicinal plants. In Khangchendzonga National Park, it was observed that migration movements match with seasonal fodder resource availability [22]. Shepherds during en route migration face constraints such as food, fodder, water deficit, veterinary facilities, wild animals, predators, and sometimes road accidents of their livestock. Such constraints have also been reported by many previous studies [23-26]

\section{DISCUSSION}

It is also emphasized that sufficient interest has not been put in conserving and promoting traditional wild medicinal plants. The need is to adopt large scale plantation of these medicinal plants within the forests as well as along roadsides so that the migratory shepherds are benefitted. Unfortunately, deforestation activities and the changing climatic conditions have made the availability of medicinal plants as a scarce resource to the migratory shepherds. Plants and plant products play an important role in the lives of these migratory shepherds. The critical review of the past work done and the results of this survey suggest that wild medicinal plants are very important for migratory shepherds living in tribal areas of Himachal Pradesh. The documentation of the ethnobotanical approach is an improvement for enhancing the understanding of native knowledge systems $[27,28]$. The present trends for surviving healthy long life entirely dependent on the traditional medicines and it possesses several natural constituents to eliminate the critical causes of the disease [29,30]. Plants are a rich source of free radical scavenging molecules such as terpenoids, vitamins, lignins, phenolic acids, flavonoids, tannins, quinones, alkaloids, coumarins, betalains, amines, and other metabolites which are rich in antioxidant property. The antioxidants property in plant products helps in the stimulation of biological system against oxidative damage [31-33]. In the modern day world traditional ethnomedicinal plants play a significant role in the health-care system, but due to lack of interest between the younger generation and their tendency to migrate to cities for lucrative jobs, a wealth of traditional knowledge is decreasing. The need of the hour is to harness this important traditional knowledge and preserve this traditional knowledge for the benefit of future generation. The information generated from the study regarding the ethnomedicinal plants used by tribal migratory shepherds needs a through phytochemical investigation including phytochemical extraction and isolation along with few clinical trials. This could help in creating mass awareness regarding their conservation within the region.

\section{CONCLUSION}

In the present investigation, the traditionally using plants as medicinal value by migratory shepherds a tribal community of Western Himalaya were identified. They are using the plants for cough, cold, fever, asthma, skin allergy, bone fracture, abdominal pain, jaundice, body pain, bone fracture, malaria, wound healing, etc., in various forms such as decoction, powder, paste, and juice. The foremost important thing is to give awareness and training to tribal migratory shepherds on a multidimensional basis about sustainable utilization of wild medicinal plant wealth in the hillside management for plant resources. This valuable survey may be useful to improve the pharmaceutical and application in the future.

\section{ACKNOWLEDGMENT}

We are grateful to the migratory shepherds and local peoples of the study area for their cooperation in providing valuable information about 
ethno aspects. Thanks to experts from BSI Dehradun, Uttarakhand, and FRI Dehradun, Uttarakhand for the identification of ethnomedicinal plant specimens collected from study sites.

\section{AUTHORS' CONTRIBUTIONS}

The concept, design, and questionnaire of the study were done by Radha. Fieldwork and literature study was done by Radha. Interpretation of data was prepared by Radha, Dr. Sunil Puri and Dr. Sanjeev Kumar. Revision of the article was done by Radha and Dr. Sanjeev Kumar.

\section{CONFLICTS OF INTEREST}

We declare that we have no conflicts of interest.

\section{REFERENCES}

1. Singh JP, Roy MM, Radotra S. Technical Bulletin. Jhansi: Grasslands of Himachal Pradesh. Director, Indian Grassland and Fodder Research Institute; 2009

2. Myres N, Mittermeier RA, Mittermeier CG, da Fonseca GA, Ken J. Biodiversity hotspots for conservation priorities. Nature 2000;403: 853-8.

3. Wildlife Institute of India. Protected Areas of Himachal Pradesh; 2014. Available from: http://www.wii.gov.in

4. Negi KS, Gaur RD, Tiwari JK. Ethnobotonical notes on the flora of Hariki Doon (district Uttarakashi), Gharwal Himalaya UP, India. Ethnobotany 1999;11:9-17.

5. Khanna KK, Ramesh K. Ethno-medicinal plants used by Gujjar tribe of Sharanpur district, Uttar Pradesh. Ethonobotany 2000;12:17-22.

6. Chauhan NS. Important medicinal and aromatic plants of Himachal Pradesh. Indian Forester 2003;129:979-98

7. Thakur R, Singh R, Saxena P, Mani A. Evaluation of antibacterial activity of Prosopis juliflora (SW.) DC. Leaves. Afr J Tradit Complement Altern Med 2014;11:182-8.

8. Sharma PK, Lal B. Ethnobotanical notes on some medicinal and aromatic plants of Himachal Pradesh. Indian J Tradit Knowl 2005;4:424-8

9. Rawat DS, Kharwal AD. Ethnobotanical studies of weed flora in Shivalik Hills, Himachal Pradesh, India. Int J Adv Res 2014;2:218-26.

10. Singh KN, Kumar A, Lal B, Todaria NP. Species diversity and population status of threatened plants in different landscape elements of the Rohtang Pass, Western Himalaya. J Mountain Sci 2008:5:73-83.

11. Dutt B, Nath D, Chauhan NS, Sharma KR, Sharma SS. Ethnomedicinal plant resources of Tribal Pangi valley in district Chamba, Himachal Pradesh, India. Int J Bioresour Stress Manag 2014;5:416-21.

12. Kumar N. Some plants used as cardiac stimulants, blood purifiers, purgative and antispasmodic in Unani system of medicine from Joginder Nagar (H.P.). Indian J Fundam Appl Life Sci 2014;4:427-32.

13. Singh KN, Batish DR. Most prominent ethno-medicinal plants used by the tribals of Chhitkul, Sangla valley. Ann Plant Sci 2015;4:943-6.

14. Sharma PK, Chauhan NS, Lal B. Studies on plant associated indigenous knowledge among the Malanis of Kullu district, Himachal Pradesh.
Indian J Tradit Knowl 2005;4:403-8.

15. Chowhery HJ. Himachal pradesh. In: Mudgal V, Hajra PK, editors. Floristic Diversity and Conservation Strategies in India Vol II: In the Context of State and Union Territories. Calcutta: BSI; 1999. p. 845-94.

16. Singh SK. Ethnobotanical study of useful plants of Kullu district in Northwestern Himalaya, India. J Econ Tax Bot 1999;23:185-98.

17. Botanical Survey of India. Flora of India. Kolkatta, India: Botanical Survey of India; 1996

18. Kaur H, Sharma M. Flora of Sirmaur (Himachal Pradesh). Dehradun: Bisen Singh Mahendra Pal Singh; 2004. p. 770.

19. Kumaravelu N, Murallidharanand R, Sivakumar T. A study on migratory sheep production systemin southern agro climatic zone of Tamil Nadu. Indian J Small Rumin 2008;14:137-40.

20. Balamurugan V, Krishnamoorthy P, Veeregowda BM, Sen A, Rajak KK, Bhanuprakash V, et al. Seroprevalence of peste des petits ruminants in cattle and buffaloes from Southern Peninsular India. Trop Anim Health Prod 2012;44:301-6.

21. Sharma PK, Chauhan NS, Lal B. Commercially important medicinal and aromatic plants of Parvati Valley, Himachal Pradesh. J Econ Taxonomic Bot 2003;27:937-42.

22. Thakur K, Puri S. Ethnobotanical plants of bandli wildlife sanctuary, Mandi, Himachal Pradesh. Int J Adv Res 2016;4:106-8.

23. Tambe S, Rawat GS. Traditional livelihood based on sheep grazing in the Khangchendzonga national park, Sikkim. Indian J Tradit Knowl 2009;8:75-80.

24. Rao KA, Rao KS, Rao SJ, Ravi A, Anitha A. Studies on migration of sheep flocks in north coastal zone of Andhra Pradesh: Identification of traditional migration tracts. Indian J Small Rumin 2011;17:260-3.

25. Suresh A, Gupta DC, Mann JS. Trends, determinants and constraints of temporary sheep migration in Rajasthan-an economic analysis. Agric Econ Res Rev 2011;24:255-65.

26. Kaintura S, Kumar N, Kothiyal P. Correlation of antihypertensive drugs and new onset diabetes: A review. Int Res J Pharm 2017;8:36-40.

27. Kalaiselvan M, Gopalan R. Ethnobotanical udies on selected wild medicinal plants by irula tribes of Bolampatty valley, Nilgiri biosphere reserve (NBR), Southern Western Ghats, India. Asian J Pharm Clin Res 2014; 7:22-6

28. Ranganathan R, Vijayalakshmi R, Parameswari P. Ethnomedicinal survey of Jawadhu hills in Tamil Nadu. Asian J Pharm Clin Res 2012; 5:45-9.

29. Agarwal P, Mishra A. Pharmaceutical quality audits: A review. Int J Appl Pharm 2019;11:14-22.

30. Maurya H, Kumar T. Formulation, standardization and evaluation of polyherbal dispersible tablet. Int J Appl Pharm 2019;11:158-67.

31. Ansari N, Chandel D. Antioxidant studies on methanol and aqueous extracts of Gymnosporia montana plant. Int J Pharm Pharm Sci 2019; 11: $65-70$.

32. Arirudrai B, Janani B, Rao US. Evaluation of antioxidant and chemopreventive potential of methanolic extracts of leaf of Aegle marmelos attributes towards ductal carcinoma studied in mcf 7 cells. Int J Pharm Pharm Sci 2019;11:21-5.

33. Sharma M, Biswajit D. Medicinal plants of North-East region of India: A small review. Int J Curr Pharm Res 2019;10:11-2. 